\title{
Lacking, Needing, and Wanting
}

In this paper I offer a novel conception of the nature of wanting. According to it, wanting is simply lacking something one needs. Lacking has no direct connection to goodness but needing does, and that is how goodness figures in to wanting. What a thing needs derives from what it is to be a good thing of its kind. In people, wanting is connected to both knowledge and choice, since a person can know that she wants something and can act on that knowledge. When she does, she is acting in light of that want and her want is a reason why she acted. But while wanting is thus connected to our rational capacity for action, wanting is not itself a capacity or a disposition to act, and it does not cause or generate the action. Acting in light of a want is no different from acting in light of any other fact. Still, there is a close connection between wanting and our wills, not just because we can sometimes choose how to get what we need, but because our choices can determine what we want. We can't simply choose to want something, but in deciding how to live our lives, who to be, and what to pursue, we are free to settle what we want, at least within limits. These connections to knowledge and the will make human wanting rich and morally relevant, but they don't transform human wanting into something special. Wanting is everywhere just a matter of lacking something one needs. That, in very broad strokes, is the picture I will spell out.

I anticipate two immediate objections. First, don't needs and wants come apart? Can't a person want something (e.g., another scoop of ice cream) without needing it and need something (e.g., exercise) without wanting it? Second, aren't our wants transparent to us in a way that our needs are not? We often know what we want, but we don't always know what we need. We can think we need something when we don't, and not realise that we need something when we do. 
Don't these objections show that wanting something just cannot be the same as lacking something one needs? Don't they show that my proposal is doomed from the start?

I think my view can offer plausible answers to these objections, answers that cast new light on the notoriously dark links between wanting, choice, deliberation, and self-knowledge. Here, briefly, are five points we need to keep in mind. First, our wants can differ along many dimensions. They can vary in urgency from slight to pressing to dire; they can have a wide variety of sources; and it is sometimes a matter of choice how to fill them. We can choose another scoop of ice cream, not to satisfy a pressing biological necessity, but just because everybody needs a little joy at times and ice cream can do the trick. Second, our needs and wants can conflict in complex ways. We can want to exercise to stay healthy and also want to not exercise in order to finish a book manuscript. Third, we are not always pleased by our wants. We can wish we didn't want something knowing full well that we do. Fourth, familiar conversational factors affect how we say what we and others want and need. ${ }^{1}$ We may say we don't want to exercise, meaning only that we wish we didn't need to. And we may say we merely want ice cream, so as not to exaggerate its urgency or importance. Fifth, we are understandably most interested in those wants we know we have. They can be a reason for action, and we make sense of others in terms of the wants (we think) they take themselves to have. Recognising our special interest in known wants should not obscure the fact that we are sometimes mistaken or ignorant about what we want.

Crucially, none of this requires denying that wanting is anything but lacking something needed. These quick remarks can only gesture at some of the resources my view has to address

\footnotetext{
${ }^{1}$ For an excellent discussion of this, see (Gregory 2017b).
} 
these objections. A full response would take us beyond this paper, but I hope that what follows makes this view of wanting seem plausible and makes good on the claim that it casts interesting new light on wanting, knowledge, and the will. I also recognise that some will say that our words 'want' and 'desire' are polysemous and that, at most, I am drawing attention to one use of them. I feel some attraction to this myself, but I also think that there is value in seeing just how far we can get in understanding deliberation, choice and action if we start with a simple and clear view of wanting.

It will help to make explicit how my view contrasts with standard ones in the literature. In general, standard views hold that wanting is a psychological or mental state whose "hallmark...is that it moves us to act." (Marks 1987). I reject both strands in this view. First, I deny that wanting is an inherently mental or psychological state or condition. On my view, it has none of the characteristic marks of the mental. It is not intentional (Searle 1983), it is not a representation of a need (Stampe 1987), or an appearance of a good (Oddie 2017, Tenenbaum 2007), or an awareness of reasons in favour of doing something (Scanlon 2000; Milona \& Schroeder 2019). Nor is wanting a sort of judgment or belief (Gregory 2012 and 2017). It is not essentially self-conscious and does not invariably involve emotions or passions. Second, I deny that wanting has a special connection to motivation. Wanting something is not intrinsically motivating (Schapiro 2009), a cause of intentional actions (Armstrong 1968, Davidson 1963), a behavioural disposition (Stalnaker 1984, Smith 1994, Alvarez 2017), or a form of action itself (Thompson 2008). Wanting is just lacking something one needs. When you know you want something, you can act on that knowledge. But this is no different than acting on any other fact. Still, I agree with proponents of the standard view that a person's wants are of fundamental importance in her practical life. But their importance is dependent, it seems to me, 
on knowledge and the will. The path of self-discovery is in part a matter of learning more about what we need and want. As we choose the flow and form of our lives, we shape our wants, at least within limits that derive from what we ought to want, and ultimately from how we ought to be. These connections to knowledge, deliberation, and choice ground what is distinctive and special in human wanting. But to understand this correctly, it seems to me, we do best to think of wanting as just lacking something one needs.

Here is my plan. In section 1, I will develop the basic idea and discuss how goodness fits in. In section 2, I will defend the idea that wanting is not an essentially mental or psychological condition. In section 3, I will consider knowing what one wants and what is involved in acting on this knowledge. In section 4, I will look at how our will can influence what we want and at the limits to this influence.

\section{Wanting, Lacking, and Needing}

My focus will be on wanting, but as Graham Oddie notes, we have a very rich vocabulary for saying and characterising our wants.

I take desire and want to be synonyms that denote what might be called a thin concept, a determinable of which there are various thick determinates. We have quite a rich vocabulary for different determinates of desire: crave, hanker, yearn, wish, hunger, long, and fancy, among others. There are also closely related concepts, such as like and love, that may involve desire, although it is not immediately clear that they are just determinates of desire. They may, however be concrete realizations of desire. That is, they may be constituted by desire together with additional features. (Oddie 2017, 30) 
Craving and hankering involve an urgency missing from fancying and wishing. ${ }^{2}$ Longing and yearning seem more passive than hungering, though all three involve feeling. Liking, caring about, and loving seem to differ in stability or centrality. My likes can shift more easily than my loves. The connections between these various things need more exploring than I can give them. Importantly, though, all of them seem to involve self-awareness. Ordinarily, one can't fancy, crave, long for, love, or prefer one thing to another without knowing about it. ${ }^{3}$ I think our

${ }^{2}$ Cravings and hankerings are like urges in having a phenomenology. We feel their pull or push, even when we prefer not to be moved by them. It may be a terminological matter whether to call such cravings and urges "desires". Harry Frankfurt called them our "most elementary desires". (Frankfurt 2002, 184). But I think it is better to treat these feelings separately from wanting. I can want something without feeling a craving for it, and crave something I don't want. For more on this, and on what a theory of desire is a theory of, see (Schapiro 2014).

${ }^{3}$ Love and other deep commitments are of central importance in understanding human life, but as Oddie notes these commitments are also very sophisticated, crucially involving not just selfknowledge but choice. My love for my family, my chosen profession, and even my hobbies can give rise to needs and thereby to what I argue are wants. But it is a mistake, I think, to see loving as a form of wanting, even as a sophisticated form of it. I don't have space to develop this point, and anyway my interest here is in detailing a conception of wanting. My thinking about love is deeply influenced by Harry Frankfurt's work, especially his (1982). 
knowledge of our wants is of central importance in understanding human life and action, but I think it is best to start with wanting itself. I'll return to self-knowledge in section $3 .{ }^{4}$

Oddie decides to focus on "desiring", but I will focus on "wanting". As Dennis Stampe notes, the word "desire” is 'an awkward verb, but a natural noun' (Stampe 1986, 168). In its natural use as a noun, "desire" is familiarly ambiguous between what a person desires and their desiring it. While it is fairly easy to distinguish a desire from its object, it is also easy to be lured into thinking of desires as themselves object-like, as entities that can have semantic, phenomenological, normative and even causal properties. The same temptation arises with “belief”, and I warn about it in other work (Hunter 2018; Forthcoming). I think we must resist the temptation to hypostasize believing and desiring if we are ever to understand their natures. Unlike "desire", the word "want" is most naturally used as a verb, and does not so easily give rise to those temptations, and that is why I will focus on it.

The idea that wanting is lacking something needed fits the original meaning of the English word "want." The Universal OED says that a want is a "deficiency, shortage, or lack of

\footnotetext{
${ }^{4}$ Oddie might have added preferring one thing to another to his list, in the sense of assigning a greater value or expected value. This notion plays a central role in formal decision theory. It seems to me that it is not the same as wanting. I may believe that one umbrella is much better than another, and so prefer the first to the second, without wanting either one. And I may (or so I will argue) want something without knowing it, and so without having any relevant preferences regarding it. Preferring seems to involve knowledge in ways that wanting does not.
} 
something desirable or necessary". ${ }^{5}$ It offers "Victorian houses which are in want of repair" as an example. Webster's defines the verb "to want" as to be needy or destitute, and offers "The motor wants a tune-up", while the OED offers "The wheel wants greasing". Both dictionaries trace the word back to the Old Norse word "vanta", similar they say to the Old English word "wan", both of which they say mean deficiency. My account of wanting is inspired by these linguistic points, but they are not meant to be an argument in favour of it. I think the value of my view of wanting comes from the new and interesting light it sheds on the connections between wanting, willing, knowing and acting.

According to the OED, the original notion of "want" was extended early on from lack to need. But lacking something and needing it are not the same. A thing can lack something it does not need. A clean set of gears, for instance, lacks dirt but does not need any. And a thing can continue to need something even after it has got some of it. A set of gears still needs oil even after it has been thoroughly oiled, though it may not need more oil, or it may not need any at the moment. I will understand lacking as a simple matter of not having.

LACK: X lacks $\mathrm{Y}$ if $\mathrm{X}$ does not have (or is not) $\mathrm{Y}$

It is the notion of needing that will do the interesting work on my account.

\footnotetext{
5 This use of "want" to ascribe an unmet need to something is noted by T.F. Daveney, who offers "Peter wants a new coat" as an example of it (Daveney 1961). Daveney says that a person can want something without knowing it. Rather than focus on it, though, Daveney's article concerns wanting to do what one is intentionally doing, and the connections between this want and the action's causes. As he notes, we characteristically know about such wants. The presence of this self-knowledge, it seems to me, indicates that this sort of case of wanting is not fundamental.
} 
It seems to me that what a thing needs depends on the sort of thing it is. ${ }^{6}$ There are different sorts of things, different sortal properties. Being a pebble is a sortal property, because pebbles are a sort of thing. So are the properties of being a chair, being a person, and being a solar eclipse. Some sortal properties are goodness fixing and others are not. All I mean is that for some sortals there is such a thing as being a good or better case or instance of it. I assume that being a pebble is not a goodness fixing sortal property, for no pebble is a better pebble than another. Likewise, being a puddle, being a cloud, being a stain, and being a galaxy are not goodness fixing sortals. No galaxy is a better galaxy than any other. By contrast, being a knife is a goodness fixing sortal because one knife can be a better knife than another. The same is so for other artefactual sortals, such as being a chair, being a pen, and being a gear shift. With such artefacts, the goodness is a matter of something like proper function or operation. One knife is a better knife than another if it is better at doing what knives are meant to do. What it takes to be a good knife is set or fixed by what knives are for.

A thing can fall under different sortals, and one might be goodness fixing while another is not. A knife is also an object, but no object is a better object than another. Being an object is not a goodness fixing sortal. A thing can also fall under many goodness fixing sortals, and it might be a good thing of one kind but not of another. A knife can be a good paper weight but a poor knife. A pebble can be a very good paperweight even if it cannot be a good pebble. So in asking whether a thing is good in this attributive sense we need to specify a sortal under which it falls.

\footnotetext{
${ }^{6}$ What follows relies on the discussion of goodness in (Thomson 2008). Her views can be traced back to (Anscombe 1958), (Geach 1956), and (von Wright 1963).
} 
With living things matters are more complex. I take it that there is such a thing as good condition for a rose bush, and that one rose bush might be in better condition than another. In this sense, one rose bush may be healthier than another. Health in a rose bush is in some ways like but in other ways unlike health in a pine tree or an orchid, and this is why each species has its own characteristic needs. What constitutes being healthy is set by the biological nature of the plant. Animals also have standards for health, and they too vary from species to species. Unlike plants, though, animals have emotional lives, and a battered dog suffering through emotional pain is not fully healthy. Emotional life varies from species to species and so do emotional needs.

Activities, jobs, and tasks are sortals and some of these are goodness fixing. Rolling down a hill is an activity, I suppose, but there is no such thing as a better or worse rolling down a hill. Likewise for moving through the air. Photosynthesizing, on the other hand, is a goodness fixing activity sortal. Some plant species are better at photosynthesizing than others. They do it more efficiently or in a wider variety of conditions. I take it that some beavers are better than others at chewing though bark and at constructing lodges. So those tasks are goodness fixing sortals too. ${ }^{7}$ People have jobs and these jobs usually set a standard of goodness, of what it takes to do the job well. I'll say more about people in sections 3 and 4 when I discuss knowledge and choice. But for now I want to stay with relatively simple cases.

\footnotetext{
7 Though some act-types are goodness-fixing sortals, being an action is not. No particular action is a better action than any other. I am inclined to think it follows that no agent is a better agent than any other, either. Of course, one agent might be a better person than another, or a better parent, or a better tennis player, or etc., but this would not make them a better agent. I won't pursue this here.
} 
I suggest we accept the following.

NEED: $\mathrm{X}$ needs $\mathrm{Y}$ only if $\mathrm{X}$ is an $\mathrm{S}$ and a good $\mathrm{S}$ is or has $\mathrm{X}$.

I will mention some complexities that I will set aside. One is that we can distinguish instrumental from constitutive needs. A knife needs to be sharp and it needs to be properly stored. Being sharp is a constitutive need, part of what it is for a knife to be a good one. Being properly stored is an instrumental one, something it needs in order to satisfy a constitutive need. A rose bush needs a strong root system to be healthy and it needs to be in well-drained soil in order to absorb the nutrients it needs. The first is a constitutive need, the other is an instrumental one. I'm not sure how to define this difference, and I am sure it is a blurry line. I don't think these things will matter for what I want to say here about wanting.

Another complexity is that attributive goodness comes in degrees. One knife might be a much better knife than another; one rose might be much healthier than another; one dog might be much happier than another. Likewise, needs also come in degrees. A geranium plant needs water more than it needs nighttime darkness. But it needs both, as it can't be healthy without either one. Dogs need food more than they need social contact with other dogs, but they need both things. An instrumental need might also be more urgent than a constitutive one. Getting clear on all of this is complex and the details won't matter in what follows.

I have formulated NEED as a necessary condition. One reason for this concerns our power of choice. Suppose that Susan decides to be an assassin. There are things one needs to be a good assassin. A powerful and compact weapon, perhaps. But what if Susan ought not to be an 
assassin $?^{8}$ In that case, it seems to me, Susan might not actually need the things that a good assassin needs, or at least not need them in virtue of being an assassin. That's why I formulated NEED as only a necessary condition. I think this is a very important point and I'll return to it in section 4 .

Consider now the following.

\section{WANT*: For $\mathrm{X}$ to want* $\mathrm{Y}$ is for $\mathrm{X}$ to lack $\mathrm{Y}$ and to need $\mathrm{Y}$.}

The thirsty geranium needs water and lacks it. So the geranium wants* water. Its wanting* water consists in the combination of its needing water to be a healthy geranium and its lacking water. Likewise, the rusting gear wants* oil because it needs oil and it lacks it. Its wanting* oil consists in the combination of its lacking oil and its needing oil to operate well. My knife needs to be sharp but it does not want* sharpness because it is already sharp. It does not want* sharpness because one of the two conditions needed for its wanting* sharpness is absent. The rose bush lacks arsenic, but it does not want* it because it does not need it. Wanting* is simply a matter of lacking something that is needed to be a good thing of some kind or other.

People lack things they need and so have wants*. A drowning person wants* oxygen; a hungry person wants* food. For a person to want* something is just for her to lack it and need it. Of course the things a person wants* are much more complex than the things that knives and rose bushes want*, but that is only because people are much more complex. Human health is

\footnotetext{
${ }^{8}$ The point is not restricted to people. Suppose that Fido is a trained fighter dog, and that a good fighter dog is vicious and easily provoked. And suppose that to remain vicious and easily provoked Fido needs to be regularly abused. None of this entails that Fido needs to be regularly abused, because after all Fido ought not to be a fighter dog.
} 
more complex than rose health, and there are many things that people need to have, get, and do to be and remain healthy. Our emotional health is also complex, giving rise to a variety of emotional and social needs. Humans also have a variety of roles and occupations, each of which can give rise to needs and, if what is needed is lacking, wants*. Parents want* certain things in virtue of being parents, and teachers want* certain things in virtue of being teachers. Because people fall under many sortals at any one time, people have complex collections of wants*. (And these differ along a variety of dimensions of stability, urgency, and importance.) Still, none of this shows that wanting* in people is any different than wanting* in knives and Victorian windows. In every case, the sort of thing that makes it true of some person that she has a want* is what makes it true of some knife or plant that it has a want*. In every case, wanting* is just a matter of lacking something needed.

Here now is my account of wanting.

WANT: For $\mathrm{X}$ to want $\mathrm{Y}$ is for $\mathrm{X}$ to want* $\mathrm{Y}$.

According to WANT, wanting just is wanting*. I know many will object that there is much more to human wants than wants*. I agree that to understand the full phenomena of human wanting, we need to attend to aspects of us that are missing from knives, plants, and some other animals. Unlike knives and gears, we have feelings, we can know that we want* things, we can act on our wants, and what we want is to some extent a matter of choice. Our capacities to feel, know, and choose make a difference to how we experience our wants and, more importantly, to what we can and do want. But the fact that we have the capacities does not, I think, make any difference to what makes it true of a person that she wants something. In every case, wanting is just a matter of lacking something one needs. That, anyway, is the view I think we should explore. 


\section{Wanting and psychology}

If the dictionaries are right that windows, motors and wheels can want things, then wanting is not invariably a psychological state or condition. For windows, gears and plants don't have psychological states. The wheel's wanting grease would be, I suppose, a mechanical condition. The rose's wanting water would be a biological one. There would be nothing essentially psychological or mental about wanting. For there is nothing psychological or mental about either lacking or needing. This may seem like a radical doctrine. But I think it is not so radical as it might sound. For a lot of what seems psychological or mental about human wanting has to do, or so I will suggest, with feelings, knowledge, and the will. I'll discuss feelings at the end of this section, and knowledge and the will in sections 3 and 4. But first, it is worth making clear why wanting* something is not a mental or psychological state. Doing this will force us to consider why we think that wanting is.

There are different views about what marks a state as psychological or mental. One is that psychological states are intentional or representational. There are different ways to flesh out this idea. One might say that Jones' belief that the 504 stops at Garden Avenue is about the 504 streetcar and about Garden Avenue, or that it true or false depending on whether the 504 does indeed stop there, or that believing is a relation to a proposition that is by its very nature a representation. Analogous claims are sometimes made about wanting: that a person's desires are representations of objects and features of the world, that a want is satisfied just in case some state of affairs obtains, or that wanting is a relation to a proposition, that of wanting it to be true. Here is how Dennis Stampe puts this analogy.

The satisfaction of a desire is to the desire the same thing as the truth of a belief is to the belief. It is a purely semantic property. It is nothing more than the truth 
of the proposition expressed by the complement of a sentence ascribing the desire, or the belief, to someone or something. It is the truth of $\mathrm{p}$ in the schema $S$ wants it to be the case that $p$ - just as the truth of a belief is the truth of $p$ in the schema $S$ believes it to be the case that p. (Stampe 1987, 151)

Just as a person who believes something is right just in case the proposition that individuates their belief is true, so a person who wants something is satisfied just in case the proposition that individuates their desire is true.

I'll return in a moment to wanting, but it is clear that wanting* is not intentional or representational in any of these senses. The wheel's wanting* grease is not about grease, and is neither true nor false nor correct nor incorrect depending on whether some fact obtains, and wanting* grease is not a relation to a proposition. The wheel's wanting* grease consists in its needing and lacking grease, but lacking and needing are not intentional or representational states. The same is true when a drowning person wants* air. Her wanting* it is not a representation of air. So wanting* is not intentional or representational in these senses. It lacks this mark of the mental.

In other work, I have argued against this representational view of believing (Hunter, forthcoming). I have suggested, instead, that to believe something is to be correct or incorrect depending on how things are. Still, on my view, belief states can be individuated by propositions. That is, believing that $\mathrm{p}$ is believing that $\mathrm{q}$ just in case the proposition that $\mathrm{p}$ is the proposition that q. But being individuated by a proposition is not enough to make a state a mental one. For states of wanting* can also be individuated by propositions. If Stampe is right that wanting is always wanting some state of affairs to obtain, then the same is true of wanting. The wheel that lacks the grease it needs wants* it to be the case that it has grease. That want* is filled or 
satisfied when the proposition that the wheel has grease becomes true. The drowning person who lacks the air she needs wants* it to be the case that she has air. That want* is filled or satisfied when the proposition that the person has air becomes true. And these wants* can be individuated by the associated proposition. Wanting* $\mathrm{X}$ is the same as wanting* $\mathrm{Y}$ just in case any proposition whose becoming true would satisfy the first would also satisfy the other. But, as we have seen, there is no sense in which needing and lacking are mental. So being a state individuated by a proposition cannot be sufficient for being a mental state.

I am happy to count believing a mental or psychological state, even though I deny that belief states are representational. And I am certain that wanting* is neither psychological nor intentional. Wanting* is just lacking something needed, and it is hard to see how this can be psychological or mental. But what should we say about wanting? If I am right that being individuated by a proposition is not enough to make a state representational, then this may allow us to say that wanting is also not representational. But if it not representational, then we need another reason to think it is psychological. ${ }^{9}$

\footnotetext{
${ }^{9}$ It might seem that wanting is intensional and even hyper-intensional, and that this both distinguishes it from wanting* and makes it essentially mental. Odysseus, after all, seems to want to marry Jocasta but not to marry his mother, even though she is his mother. And Emily, it seems, wants Santa to bring her a red sleigh. These are hard cases. All of them involve a deep confusion or error that is hard to understand. Odysseus is confused about who is who, and Emily is mistaken about what things there are. These confusions and errors make their cases hard to make sense of. Moreover, in all such cases, the person believes that he or she wants the thing, and a person can mistakenly believe she wants something. Odysseus thinks he does not want to
} 
Psychological states are often taken to have a distinctive connection with action. At the very least, psychological states are supposed to make a difference to what a thing is likely to intentionally do. If so, then wanting* is unlike psychological states in that way. To start, wanting* is not a disposition or a capacity. Lacking something is not a disposition or capacity, and neither is needing something. The fact that a wheel needs greasing is not a dispositional fact about it. No doubt the wheel has a variety of dispositions and capacities. But its needing grease is not one of them. Wants* are conditions, like being tall, or being old, or being in Toronto, or being well-groomed. None of these is a dispositional state, and neither is wanting*.

Moreover, a thing can have a want* without being able to do anything to satisfy it. A dull knife can't do anything to sharpen itself. A dry gear cannot do anything to oil itself. This is not, I think, because knives and gears can't do things. Knives can cut things and gears can turn things, so I am inclined to think that knives and gears can act. But they are not able to do things to satisfy their wants*. In this sense, wants* are not intrinsically motivating states. Wants* are not states that prompt or incline a thing to do something to satisfy them.

Living things are different from knives in this respect. Living things are able to do things to satisfy certain wants*. A sunflower can move itself to get the light it needs. In doing so, it acts to satisfy a want*. Living things have various mechanisms that help them get some of the things

marry his mother and Emily thinks she wants Santa to bring her a red sleigh. As I will argue in section 3, we can explain a person's thoughts, actions, and feelings in terms of false beliefs about what they want, without needing to ascribe to them the apparent want. I suggest we not base a general account of wanting on cases that are hard to understand and that seem to essentially involve self-consciousness. 
they need. Here too, though, the sunflower's wanting* light is not a dispositional fact about it. Its wanting* light is just its lacking needed light. When a thing acts to satisfy a want* the action is not an exercise of that want*. To be sure, the sunflower exercises a power when it moves to the light, but that power or ability is not a want*. When it moves to the light, the sunflower is exercising an ability it has whose exercise satisfies that want*. But it is not exercising that want*. In this sense, wants* are not intrinsically motivational or active states.

When a sunflower moves because it wants* light, does that want* cause the motion? Views on the nature of causation differ, and there is disagreement about whether conditions and states can be causes. This debate arises for beliefs and other admittedly psychological states as much as it does for wanting*. But however that debate gets settled, it will remain true that a want* might play no causal role at all in the activity of a capacity whose exercise satisfies that want*. It may be, of course, that the sunflower's wanting* light triggers the exercise of its ability to move. Perhaps the capacity is sensitive to the want*. But perhaps the sunflower's movement is triggered by a distinct condition that happily coincides with the sunflower's wanting* light. Or maybe the power is constantly exercised and it is a happy coincidence that its exercise satisfies the plant's want*. I don't think anything about the want* itself will settle whether it triggers the power or not. For there is nothing in the very nature of lacking something one needs that could trigger a capacity whose exercise would satisfy it. This is so even for an infant's instinctive actions aimed at getting milk. Its reaching and suckling will satisfy the want*, and the origin of those activities as the exercise of innate capacities may be explained by the presence of the want*, but we should not identify the innate ability or its exercise with the want* itself. The want* is one sort of thing (a condition), the ability is another (a power or capacity), and the exercise is a third (an event or process). The wanting* is just lacking something that is needed. 
Unlike plants, people and others animals can act in the knowledge of a want, and this adds rational complexity to the story. I'll say more about this in section 3 after discussing knowledge.

Some psychological states have a phenomenological component. Hunger, thirst, and toothache have characteristic feels. And I am happy to count those feelings as psychological or mental. Some wants* may have associated feelings, but not all do. Plants have no feelings, I take it, but they have wants*. A person who wants* water might feel thirst, but apparently that feeling will disappear after a while. The feeling of thirst is a sign of wanting* water, but the want* and the feeling can each occur without the other. That feeling is not the wanting*. Alleviating the feeling of thirst is not the same as satisfying the want*. And of course some wants* are not associated with any characteristic feeling at all. A person may want* more protein than she is getting, but there is no characteristic feeling associated with that want*. ${ }^{10}$

Let me take stock. I have been detailing how wants* differ from psychological states and conditions. They are not intentional or representational, not even in the thin sense of being about things and properties. Wants* do not have correctness conditions, though they can be satisfied.

\footnotetext{
${ }^{10}$ William Alston (Alston 1973, 402) traces the idea that wanting is a feeling or passion to a cluster of early-modern ideas: a Rationalist conviction that states of consciousness are more easily known than bodily ones and an Empiricist rejection of Aristotelian metaphysics. Add to these the hope that we might explain rational action in terms of conscious analogues for the mass and force that explain the motions of physical bodies, and we get the view of wanting as a conscious feeling that works with believing to propel rational bodily movements. This view of wanting retains power, even as we have abandoned the views and explanatory ambitions that prompted it.
} 
Wants* are not intrinsically connected to action. They are neither dispositions nor capacities. And they do not all have characteristic phenomenology. Perhaps none of this is surprising. Wanting* is just lacking something one needs, and surely no one is tempted to count this a mental or psychological condition. But if WANT is true--if wanting just is wanting*--then wants too are not psychological states. This would be a surprising result. Most philosophers have taken human wants and desires to be fundamentally different from the wants* of knives and sunflowers. I suggest, though, that the differences derive, not from the nature of our wanting, but from the fact that we can know what we want and can influence what we want through our choices and decisions. It is knowledge and choice that make us special, not our wants.

\section{Wanting and knowing}

If the dictionaries are right, then wanting is not an essentially self-conscious state. Plants, windows, and gears want things without knowing that they do, and indeed without knowing anything at all. In suggesting that a thing's wants are not self-conscious, I don't mean that they are unconscious or subconscious. I mean that they are, like facts about its height and weight, non-conscious. Still, people commonly know some of the things they want and knowing this makes a difference to what they do. This section explores the connections between wanting, knowledge, and action. For elegance, I'll dispense with the asterisks, and assume that wanting just is lacking something one needs. My strategy is to reveal how rich and relevant a person's knowledge of her wants, so understood, can be.

I take it that people can want something without knowing it, and that it is not always easy to know what one wants. This is unsurprising if knowing that one wants something is knowing that one needs it and lacks it. Consider our basic biological needs. A person can be protein- 
deficient without knowing it. Sarah might not realise that she needs more protein, and it might not be easy for her to find this out. Our bodies are complex and it has taken humans a long time to gain the knowledge we have of what it takes to be healthy. As we discover more about our biological needs, we gain a better understanding of our biological wants.

More generally, if wanting is lacking something one needs, then knowing what one wants requires knowing something about goodness. One needs to know that one falls under a sortal that sets a standard for goodness that one does not quite meet. The biological example illustrates how difficult knowing this can be. The same is true of most sortals. It is hard to know what it is to be a good father, to be a good streetcar driver, to make a good cake. Some work is usually needed to figure out how to do well at even the simplest roles, jobs and tasks. Plausibly, this is so for every interesting goodness fixing sortal under which a person can fall. What it takes to be good is almost never transparent to us. ${ }^{11}$

I also take it that people can be mistaken about what they want. They can think they want something when they really don't. This fact too is unsurprising if wanting is just lacking something one needs. For one can be wrong about what one lacks. Naveen may believe she lacks vitamin D when, as a matter of fact, her vitamin D levels are fine. She is right that she needs it, but wrong that she lacks it. Likewise, a person can be wrong about what she needs. Roberta may incorrectly think she needs more arsenic in her diet to be healthy. She's right that she lacks it, but

\footnotetext{
11 The way to answer the question "Do I want (to do) X?" is to consider whether you have some unmet need that (doing) X would likely satisfy. You can't answer this just by inspecting your conscious mental states.
} 
wrong that she needs it. Like Naveen, Roberta thinks she wants something when, in truth, she does not. At least not if wanting is lacking something one needs. ${ }^{12}$

A person who knows or thinks she wants something might try to get it. It is not essential to wanting, though, that a thing will try to get what it wants. Windows and gears can't ever try to get what they want. But many hold that, at least with people, wanting is tightly linked with action. Anscombe said that, for people anyway, "the primitive sign of wanting is trying to get" (Anscombe 1953). This suggests something like the following.

DISPOSITION: A person who wants something is disposed to try to get it. No one would accept this without qualifications. A plausible version would admit that people prioritise their wants, can want conflicting things, and can decide to ignore a want. Anyone tempted to connect wanting with trying-to-get would defend a more sophisticated account than DISPOSITION. Still, the idea of a tight link between wanting and trying-to-get informs virtually every contemporary account of wanting.

${ }^{12}$ Utilitarianism tends to blur the distinction between what a person wants and what she thinks she wants. Getting something is satisfying if one thinks one wants it, regardless of whether one actually does want it. If the goal of morality is to maximize human satisfaction, then it is what people think they want that matters. This blurring is encouraged by skepticism about whether people can ever be wrong in thinking they want something, and this skepticism in turn is supported by a broadly liberal view that doubts whether there are objective human needs. All of this, obviously, is beyond the scope of this paper. My thoughts here are influenced by (O’Neill 1989). 
But if wanting is just lacking something one needs, then DISPOSITION is on the wrong track altogether. If I am right, there is no deep link between wanting and trying to get, even when it comes to people. For wanting is just lacking something one needs, but lacking something is not a disposition and neither is needing it. Sarah may want protein in her diet, without having the slighted disposition to get any at all. She may have no clue that she wants it. As Ryle might have said, DISPOSITION involves a category mistake, if wanting is just lacking something one needs.

A slight revision to Anscombe's remark might seem to be closer to the truth: "the primitive sign of knowing that you want something is trying to get it." I agree that a person who knows that she wants something may try to get it. Sarah might eat some steak in order to get the protein she knows she wants. And the fact that she is trying to get it can be, for us, a sign that she believes that she wants it. If we know her to be reliable on such matters, it may even be evidence that she knows that she wants it. Maybe this revision is closer to what Anscombe had in mind. Her concern in Intention was, in part anyway, with the place of knowledge in intentional action and, more specifically, with the place of self-knowledge. Knowledge of what one wants fits that bill.

It anyway seems clear that when a person acts intentionally to get something that she wants she is acting on her knowledge that she wants it. ${ }^{13}$ This is central to Carl Hempel's influential account of rational action.

13 John Hyman (1999) argues that an explanation that specifies a person's reason for doing something is true only if the person knows the fact that is her reason. If this view is right, then "Susan ate the steak because she wanted to get some protein" is true only if Susan knew she wanted to get some protein. 
$[\mathrm{M}]$ any rational explanations present an agent as rationally determined by considerations which presumably the agent took consciously into account in making his decision. Let us say that a person is a consciously rational agent (at a certain time) if (at that time) his actions are rational relative to those of his objectives and beliefs which he consciously takes into account in arriving at his decisions. (Hempel 1961, 21)

The role of this knowledge in intentional action is easily missed. When Sarah eats the steak, the role of her wanting is clear. It sets the goal her eating steak is meant to achieve. The role of her instrumental beliefs is also clear. She is eating steak because she knows (or anyway believes) that eating steak is a way to get protein. More generally, she is doing something that she believes will get her what she wants. But implicit in this explanation is the assumption that she also knows (or anyway has a belief about) what she wants. More recently, Michael Smith puts this assumption by saying that when a person acts intentionally she must "put together" her want and her means-end beliefs (Smith 1994, 92). ${ }^{14}$ In eating the steak, Sarah is putting together her desire for protein and her belief that she can get some by eating steak. She can put them together only because she knows (or anyway believes) that she wants protein. She is thus acting in the

\footnotetext{
${ }^{14}$ My discussion is indebted to (Schueler 2009). He argues that a person's intentional actions are best explained by her beliefs about her desires and wants together with means-ends beliefs about how to satisfy them. The desires themselves play no essential role in explaining or motivating the action. Schueler does not, so far as I can see, connect this view of action explanation to the present account of wanting as lacking something one needs.
} 
knowledge that she wants protein. What she did was rational and intentional only because she acted in the knowledge of what she wanted.

What is involved in acting in the knowledge that one wants something? Plausibly, acting intentionally is always acting on some knowledge. One is doing what they believe would, in a world as they believe it to be, be an effective means to getting what they believe they want. Some of this believing must amount to knowledge, or so I will assume. In this respect, acting on the fact that one wants something is just like acting on any fact. Sarah knows that she wants protein and she knows that eating steak is a way to get some. In eating the steak, she was acting on both facts. She acted in light of them both. Both were considerations whose role in her deliberation make her eating the steak intelligible. When a person acts to get something she knows she wants, the fact that she wants it is among her reasons for the action. ${ }^{15}$

\footnotetext{
${ }^{15}$ Not everything a person does to satisfy a want is intentional. We blink our eyes without knowing why, that is, without knowing the need it fills or even how it fills that need. We may also know we have a want without realising we also have a capacity (innate or acquired) whose operation will satisfy it. The capacity's exercise won't then be intentional and may catch us by surprise. All of this is true of more intelligent behaviour, too. Think of complex social interactions involving verbal activity. We may come to know why we engage in them and how the specific forms they take serve the needs they do. But it comes with being a living thing that we have and acquire capacities whose natural exercise satisfies certain of our wants without our knowledge. Gaining this self-knowledge may make room for choice, which I will discuss in section 4 .
} 
What I have said about knowledge and action also helps to clarify the role of wanting in practical reasoning. As Stampe notes, when we deliberate about what to do, we reason from both our beliefs and our wants, but their roles seem different.

When we reason from our beliefs it is from what we believe- the objects of our beliefs - that we reason: the facts as we believe them to be.... Our beliefs, then, comprise reasons for us to act through their objects. But when we reason from our desires, it is not from what we want that we reason. Desires, then, cannot, in that sense, comprise reasons for acting through their objects. How then can they do so? How can practical reasoning possibly begin in desire? (Stampe 1987, 336-7; italics in original)

When Sarah wants some protein, the object of her want is protein or her having some. But if Stampe is right that a reason must be a fact, neither protein (the stuff) nor having some protein (a condition) is in the right ontological category to be a reason for action. Stampe and others respond to this by insisting that the objects of desires must be importantly like the objects of belief. But the observation that intentional action always involves knowing (or anyway believing) that one wants something suggests a simpler idea: practical reasoning starts, not in wanting something, but in knowing or believing that one wants something. It can start there even if the objects of wants are not the right sort of things to be reasons. ${ }^{16}$

${ }^{16}$ Stampe says that it "will not do to make practical reasoning begin from the proposition that one wants a certain thing: that would be nothing more than reasoning about one's desires." (347). I agree with him (and Anscombe) that "kinds of reasoning are not distinguished by their subject matter" (347). But that is because reasoning about the facts is the only reasoning there is. 
This is not to deny that a person's wants have a special role to play in practical reasoning and intentional action. When a person acts to get something they want, the fact that they want it sets a goal for the action. In acting they aim, inter alia, to satisfy the want. Sarah's knowledge (or belief) that she wants protein thus sets a goal for the action. By contrast, her knowledge that eating steak is a way to get protein does not set the goal of the action, at least not its ultimate goal. All of this deserves more attention than I can give it here. But it is worth stressing the point that acting on a want is just like acting on any other fact. This is so even if the want sets the goal for the action.

Some theorists say that a person does something intentionally only if they want to be doing it, and that this marks a distinctive sense or form of wanting. ${ }^{17}$ It is distinctive in part because the object of the wanting is an action type. Sarah wants to be eating protein, and this is different from wanting protein. I'm not sure how best to accommodate this on my view, in part because intentional action always involves knowledge and choice. When Sarah eats steak in order to get some protein, she knows she is eating it, and she knows she is eating it in order to get the protein she knows she needs. She knows that eating the steak will fill a need she knows she has. Assuming that she is not being coerced, she is eating it voluntarily, and it is because she chose steak that she is eating it rather than chicken or tofu. I'm not sure what is meant to be added to the description by saying that Sarah also wants to be eating the steak. It would be odd to add that Sarah might not want to be eating it, but isn't this because she is knowingly and

Facts about what we want are one sort of fact and it is not surprising that they are of central concern to us when we reason about what to do. My views are influenced by (Thomson 1962). ${ }^{17}$ See, for instance, (Schueler 1995) and (Schapiro 2021). 
voluntarily doing something that she chose to do? To deny that she wants to be doing it would, it seems to me, be to suggest that she does not really knows what she's doing, or is being coerced into it, or didn't choose the means she is taking. All of this make me question whether such cases really do require us to recognize a distinctive form of wanting.

On my account, practical reasoning can start from knowledge of a want. Stampe thinks there is a difficulty in an account of practical reasoning that involves only belief and knowledge. Starting from It would be good if $p$, and perhaps Only my doing A will make it the case that $p$, by what logic do we pass to I will do A? All that seems to follow is that It would be good to do A-and this neither denotes an action nor the content of an intention; further premises would yield I ought to do A, but to believe that is not to intend to do A. We confront a logical gap. And it cannot, it seems, be bridged by the addition of further beliefs. (Stampe 1987, 339; italics in original)

Practical reasoning, he says, must conclude "by force of some sort of logic" (ibid, op. cit.) in an intention or action. Aristotle, he remarks, put this by saying that the intellect itself moves nothing. I think I see the gap Stampe has in mind. A person who concludes that she really ought to do A might never do it and never even intend to do it. Such a person may have some explaining to do, but what do we, as theorists of practical reasoning and wanting, have to explain? This is not the place to explore the root springs of action. I am not persuaded that intentional action requires a force of logic. And even if it did, it is unclear to me why wanting something could do the job but knowing that you want it not. In any case, these matters will have to wait for another occasion. 
I said that a revision to Anscombe's remark may get closer to the truth: "the primitive sign of knowing that you want something is trying to get it." But it would be wrong to think this supports the following revision to DISPOSITION.

DISPOSITIONk: A person who knows she wants something is disposed to try to get it.

It is true that a person who knows that she wants something might try to get it. That is one way to respond to the fact that she wants it. But a person might instead respond to that fact by trying to eliminate the want. She might decide that the costs involved in satisfying the want are too great and instead take steps to remove the need altogether. My case of Sarah and the protein can't illustrate this, since her biological need for protein is not under her control. There is nothing she can do to remove that need. But here is another case. Sarah is a soccer coach and she knows that she lacks the training she needs to be a good one. But she also knows that the required training would fill her weekends and interfere with her family life. She knows that, qua soccer coach, she wants more training, and she knows that completing the courses would satisfy that want. Instead, though, Sarah decides to quit being a soccer coach. Quitting coaching is also an intelligible response to that want. This suggests that knowing that one wants something is best viewed as dispositionally neutral. Neither the wanting nor the knowledge of the want are intrinsically tied to any disposition.

This is relevant to a connection Stampe draws between wanting and reason. He says that wanting has a per se authority: wanting something is in itself a reason to try to get it. (Stampe $1987,344)$ If wanting is lacking something you need, then it is not surprising that wanting something can be a reason to try to get it. But Stampe overstates the authority of wanting, if he means that wanting only ever constitutes a reason to try to get. For it depends on whether the 
relevant need is removable. If it cannot be removed - as with some biological needs - then the wanting has the per se authority Stampe identifies. If it cannot be removed, then wanting it is a reason to try to get it. But if the relevant need is removable, then while the wanting remains a reason for action, it is no more a reason to satisfy the want than it is a reason to eliminate it. ${ }^{18}$ I'll $^{\prime}$ return to this in the next section when I discuss choice.

But before I get to that, I want to discuss what is involved when a person believes they want something when, as a matter of fact, they neither need nor lack it. We can start by considering how people say what they want. It seems right to understand sentences like the following as expressing beliefs.

I want more protein.

I want more coach training.

I want a new computer.

That is, in saying such a thing, a person is speaking the truth just in case what they have identified (protein, training, a computer) is something they need and lack. Assuming their assertion is sincere, the person believes what they say. But the person may be wrong in what she

${ }^{18}$ It is another matter entirely, though, whether she ought to try to get it. This depends on whether other considerations outweigh the fact that she wants it. Other needs may always be more urgent. And it may be that she ought to respond to the fact that she wants it, not by trying to fill the lack, but by trying to remove the need. 
believes. Saying that one wants something does not entail that one does want it, and neither does believing that one wants it. ${ }^{19}$

This is important to keep in mind when we consider cases where a person acts in order to get something they say or believe they want. We must not assume that they want it just because they say or believe they do. As Fred Schueler has argued, we can often offer a perfectly good explanation of a person's action without assuming that they do want what they say or think they want (Schueler 2009). Suppose we see Sarah carrying a new computer to the shop counter. When asked, she tells us that she wants a new computer because hers has broken. Let's suppose that she does need one for her work. But let's also suppose that she does not actually lack one. Perhaps she is wrong that her current machine is broken. Or perhaps unbeknownst to Sarah, her wife has already bought her a new one as a surprise. Sarah believes she needs and lacks a computer, but she is mistaken about this. It seems to me that to make sense of her actions, we don't need to say she really does want a new computer. It is enough to say that she thinks she does. She may insist she wants one when we ask, though when we tell her about her wife she may reply that she thought she wanted one. (She will likely say she mistakenly thought she lacked one.) And it is very familiar that we can explain a person's actions by ascribing mistaken beliefs to them. Suppose the box Sarah is carrying is mislabeled and contains a fax machine not a computer. We could still explain her action by noting that she mistakenly believed the box contained a computer. Just how ascriptions of error can help explain what people do needs more discussion than I can give it. And no doubt such explanations succeed only in cases where people

\footnotetext{
19 There may be some wants that a person can have only if she knows that she does. I'll return to this in the next section.
} 
are mostly right about other things, including about other things they want. My point here is just that ascribing to someone false beliefs about what they want when explaining their actions introduces nothing new and should not be overlooked in an account of action explanation.

I have tried in this section to bring out how rich and relevant a person's knowledge of her wants can be and the role such knowledge can play in intentional action and practical reasoning. I don't think there is anything very new in these observations. But I think it is worth noting that none of them forces us to view wanting as anything other than lacking something one needs. What a person wants makes a difference to what she intentionally does. But it makes this difference through her knowledge of those wants.

\section{Wanting and Choosing}

On my view, what a person wants depends on which sortals they fall under. In some cases, a person has no choice whether she falls under a given sortal. People are human beings, and this is not a matter of choice. As a result, those of a person's wants that derive from basic bodily needs are not voluntary. She may try to get what she wants, or she may ignore it, but she cannot remove it. But some sortals are voluntary in that a person can decide or choose whether to fall under them. In these cases, because the person typically knows what she decided, she also knows something about what she subsequently wants in virtue of that decision. This section explores these connections between choosing and wanting and notes an important limit to them.

As I noted in section 1, jobs, activities, and tasks can be goodness fixing sortals, and they can be voluntary. Sarah chose to be a soccer coach, and Jones decided on a career as a streetcar driver. Those are both goodness-fixing sortals, since there is such a thing as being a better or worse soccer coach or streetcar driver. And a person can lack what is needed for being good in 
that role or job. Sarah doesn't have enough free time to do the training required to be a good coach, and she knows this. Jones lacks the patience her job requires, and she knows this, which is why she is taking courses in customer relations. Roles and jobs can be more or less voluntary and people sometimes have very little choice in the matter. Most people have to have some job, and the wants that derive from that fact may be only minimally voluntary.

Activities can be voluntary and give rise to wants. Henry decided to be a cyclist, and there are things a person needs to be a good cyclist, even if only a moderately good weekendcyclist. As a result, he wants better cycling shoes, a better diet to maintain his fitness level, and more endurance for the hill climbing. He also knows it will be more enjoyable to have a higherend seat, so he wants one, even though he doesn't need it as much as he needs the shoes. He didn't realise he also wanted to carry spare inner tubes and he learned this the hard way. Some of what Henry needs as a cyclist depends on the nature of cycling itself, on what is needed for a bicycle to be good, but some depends on his own nature, on what he finds pleasurable. And these wants vary in strength. The more he learns about the activity and about himself the better he'll understand his cycling wants. He knows all of this and can act accordingly.

Specific tasks can be also voluntary and give rise to wants. Simon decided to make a chocolate cake for dessert. The recipe calls for both baking soda and baking powder, neither of which he had, so he wanted to go to the store to get some. He also decided to beat the eggs separately by hand. He knew he didn't need to do this, but his recipe recommended it and he enjoys it, so he wanted to. Here too we see the subtle variation in strength in a person wants, and how what a person wants can derive both from the nature of the task itself and their own nature.

These cases also illustrate how for some sortals one cannot fall under them without knowing it and without knowing something about the relevant goodness fixing standards. You 
can't be a cyclist and not know it. Henry knows he is a cyclist because he decided to be one. Before making this decision, he knew something about what it takes to be a good cyclist and to enjoy the activity. You can't be making a chocolate cake and not know it, and least not if you are intentionally making it. Simon knows that he is making a chocolate cake because he decided to make one. Before making this decision, he knew something about how to do it well. Neither Henry nor Simon directly decided to want something — you cannot decide to need or lack a thing. But in deciding to be a cyclist or a cake-maker each of them in effect generated wants, some of which they knew about in advance and some of which they then needed to figure out.

In this way, what a person wants can be a matter of her choice. There is an important limit to this, though, deriving from the fact that a person can fall under a sortal that she ought not to. Here is an example from section 1. Susan is an assassin and a good assassin needs a weapon. Suppose that Susan lacks one. Does it follow that she wants one? Susan, we may suppose, believes that she wants one, but as we have seen this does not entail that she does want one. Suppose that Susan ought not to be an assassin. And suppose that she ought not to have a weapon. In that case, it seems to me, there are two things we might say about whether she wants one. The options differ over how they conceive of the link between sortals and needs.

First, we might say that a thing's needs are fixed by its actual sortals, that is, those sortals that it as a matter of fact falls under. Because Susan is an assassin, she would then need everything needed to be a good one. Whether Susan ought to be an assassin would be irrelevant. We would then need to say that Susan needs something (a weapon) that she ought not to have. It is not just that she thinks she needs it. On this way of connecting needs and sortals, Susan really does need a weapon even though she ought not to have one. 
Here is an alternative. We might instead say that a thing's needs are fixed by its permitted sortals, that is, those of its actual sortals it is permitted to fall under. Susan would then need everything it takes to be a good assassin only if she is permitted to be an assassin. Merely being an assassin would not be enough. If she is not permitted to be an assassin, then she may not need a weapon at all, depending on whether having a weapon is needed by one of her permitted sortals. If not, then while she may think she needs a weapon, she'd be wrong. And if she doesn't need a weapon, then she does not want one either, even though she believes she does. She would then be mistaken about both what she wants and what she needs.

I am not sure how to decide between these two ways of speaking. I suspect the decision is purely a terminological one. But the second way of speaking helpfully reveals one more source for a potential gap between what a person might say and think she wants and what she actually wants. We saw in section 3 that a person can be ignorant or mistaken in ordinary ways about what she lacks and needs. Naveen is right that she needs Vitamin D but wrong that she lacks it. Her mistake is a familiar factual one. Sarah is wrong that she needs arsenic, but right that she lacks it. Her mistake is a normative one, in that it is about what human health requires. Susan's case suggests a different source for such error. She is wrong, not about what she lacks or about what it takes to be a good assassin, but about whether she is permitted to be an assassin. This mistake grounds a mistake about what she needs and wants. She is wrong about what she wants because she is wrong about who and what she should be.

Being a person is a goodness-fixing sortal. This means there are things a person may want in order to be a good person, and such wants are non-voluntary since one cannot decide whether to be a person. I won't try to make a list. But I want to note how knowledge and choice take on special relevance here. Knowing what one needs to be a good person is elusive in a way 
that knowing what one needs to be a healthy person or a good soccer coach or a good baker are not. Figuring out how to be a good person is not as hard as knowing how to be healthy. But it is harder than knowing how to be good at a task or activity we voluntarily set ourselves. We can't decide not to be a person. But there is room, I think, for each of us to decide for ourselves what it is to be a good one and in deciding this we can come to know what we want. This freedom is part of what it is to be a person, though there are limits here too. All of this is obviously best set aside for later, but I think the idea I have defended here - that what a thing wants depends on what is needed for it to be a good thing of its kind - can help us understand this freedom and those limits.

A final point. The cases I have discussed are simple and idealised, which made them useful for drawing out the main points of my account of wanting, but may leave the impression that my account is impoverished. I think, though, that it has the resources to understand the full richness of a person's practical life. It can allow that people, in addition to being human beings, have a great variety of needs stemming from their natures, roles, jobs, and tasks, with each of them grounding a large spectrum of wants of differing degrees of urgency and importance. Conflict among a person's actual wants is inevitable and all too common, and ignorance and error about our wants only add to this complexity, as does our ability to decide who to be and what to do. That we can know what we want makes rational action possible, and that we can choose who to be makes our wants and actions morally relevant. It seems to me that we can best 
understand this richness if we start with the simple idea that wanting is just lacking something one needs. ${ }^{20}$

\section{$\underline{\text { References }}$}

Alvarez, M. 2017. Desires, Dispositions, and the Explanation of Action. In Lauria, F. \& Deonna, J. (eds.), The Nature of Desire. Oxford: Oxford University Press.

Alston, P. 1973. Motives and Motivation. In Edwards, P. (ed.), The Encyclopedia of Philosophy. Pearson.

Anscombe, G.E.M. 1958. Modern Moral Philosophy. Philosophy, 23(124), 1-19.

Anscombe, G.E.M. 1963. Intention. $2^{\text {nd }}$ ed. Oxford: Blackwell.

Armstrong, D. 1968. A Materialist Theory of the Mind. London: Routledge.

Daveney, T.F. 1961. Wanting. The Philosophical Quarterly, 11(43), 135-144.

Frankfurt, H. 1982. The importance of what we care about. Synthese, 53(2), 257-272.

Frankfurt, H. 2002. Reply to T.M. Scanlon. In Buss, S., and Overton, L. (eds.), Contours of Agency: Essays on themes from Harry Frankfurt .Oxford: Oxford University Press.

Geach, P. 1956. Good and Evil. Analysis, 17(2), 33-42.

Gregory, A. 2012. Changing Direction on Direction of Fit. Ethical Theory and Moral Practice, 15(5), 603-614.

\footnotetext{
${ }^{20}$ I have benefited from comments from Gerhard Ernst, Alex Gregory, David Horst, Christian Kietzmann, Mark McCullagh, Constantine Sandis, Christine Tappolet, Sergio Tenenbaum, and Eric Wiland.
} 
Gregory, A. 2017a. Might Desires be Beliefs about Normative Reasons for Action? In Lauria, F. \& Deonna, J. (eds.), The Nature of Desire. Oxford: Oxford University Press.

Gregory, A. 2017b. How Verbal Reports of Desire may Mislead. Thought, 6, 241-249.

Hempel, C. 1961. Rational Action. Proceedings and Addresses of the American Philosophical Association, 35, 5-23.

Hunter, D. 2018. The metaphysics of responsible believing. Manuscrito, 41(4), 255-85

Hunter, D. Forthcoming. On Believing: Ontology, limits, and norms. Oxford: Oxford University Press.

Hyman, J. 1999. How knowledge works. The Philosophical Quarterly, 49(7), 433-451.

Milona, M. \& Schoeder, M. 2019. Desiring under the Proper Guise. Shafer-Landau, R. (ed.)

Oxford Studies in Metaethics, 14. Oxford: Oxford University Press. 121-143.

Oddie, G. 2017. Desire and the Good: In search of the right fit. In Lauria, F. \& Deonna, J. (eds.),

The Nature of Desire. Oxford: Oxford University Press.

O'Neill, O. 1989. The great maxims of justice and charity. In MacCormick, N, and Bankowski, Z. (eds.), Enlightenment, Rights and Revolution. Abderdeen: Aberdeen University Press.

Schapiro, T. 2009. The Nature of Inclination. Ethics, 119(2), 229-256.

Schapiro, T. 2014. What are theories of desire theories of? Analytic Philosophy, 55(2), 131-150.

Schapiro, T. 2021. Feeling Like It: A theory of inclination and will. Oxford: Oxford University Press.

Schueler, G.F. 1995. Desire: Its role in practical reason and the explanation of action. Cambridge, MA: MIT Press. 
Schueler, G.F. 2009. The Humean Theory of Motivation Rejected. Philosophy and Phenomenological Research, 78(1), 103-122.

Searle, J. 1983. Intentionality. New York: Cambridge University Press.

Smith, M. 1994. The Moral Problem. Oxford: Oxford University Press.

Stalnaker, R. 1984. Inquiry. Cambridge: MIT Press.

Stampe, D. 1986. Defining Desire. In Marks, J. (ed.), The Ways of Desire, London and New York: Routledge.

Stampe, D. 1987. The Authority of Desire. The Philosophical Review, 96(3), 335-381.

Tenenbaum, S. 2007. Appearances of the Good: An essay on the nature of practical reason. Cambridge: Cambridge University Press.

Thomson, J. 1962. Practical reasoning. The Philosophical Quarterly, 12(49), 316-328.

Thomson, J. 2008. Normativity. Peru, IL: Open Court.

Thompson, M. 2008. Life and Action. Cambridge, MA.: Harvard University Press.

Von Wright, G. H. 1963. The Varieties of Goodness. London: Routledge \& Kegan Paul. 